\title{
Haloarcula amylolytica sp. nov., an extremely halophilic archaeon isolated from Aibi salt lake in Xin-Jiang, China
}

\author{
Yong Yang, ${ }^{1,2}$ Heng-Lin Cui, ${ }^{1,2}$ Pei-Jin Zhou ${ }^{1}$ and Shuang-Jiang Liu ${ }^{1}$ \\ ${ }^{1}$ State Key Laboratory of Microbial Resources, Institute of Microbiology, Chinese Academy of \\ Sciences, ZhongGuanCun, Haidian, Beijing 100080, P. R. China \\ ${ }^{2}$ Graduate University of Chinese Academy of Sciences, Beijing 100049, P. R. China
}

Correspondence

Shuang-Jiang Liu

liusj@sun.im.ac.cn

\begin{abstract}
A starch-hydrolysing and extremely halophilic archaeon (strain BD-3 ${ }^{\top}$ ), isolated from Aibi salt lake in Xin-Jiang, China, was characterized phenotypically and genotypically in order to determine its taxonomic status. On the basis of its polar lipid composition, nucleotide sequences of its $16 \mathrm{~S}$ rRNA genes, genomic DNA G + C content (62.4 mol\%) and growth characteristics, the organism could be assigned to the genus Haloarcula. Phenotypic differences and low DNA-DNA hybridization values to related Haloarcula species distinguished strain $\mathrm{BD}-3^{\top}$ from recognized Haloarcula species. It is therefore concluded that strain $\mathrm{BD}-3^{\top}$ represents a novel species, for which the name Haloarcula amylolytica sp. nov. is proposed. The type strain is BD-3 ${ }^{\top}\left(=\right.$ CGMCC $1.5335^{\top}=J C M$ $\left.13557^{\top}\right)$.
\end{abstract}

The definition of the genus Haloarcula was based on the numerical taxonomy and polar lipid composition given by Torreblanca et al. (1986), adopting the generic name first suggested by Javor et al. (1982). At the time of writing, the genus Haloarcula comprises six recognized species (Fig. 1): H. vallismortis (Gonzalez et al., 1978; Torreblanca et al., 1986), H. argentinensis (Ihara et al., 1997), H. hispanica (Juez et al., 1986), H. japonica (Takashina et al., 1990), $H$. marismortui (Elazari-Volcani, 1957; Oren et al., 1990) and H. quadrata (Oren et al., 1999). A common feature of representative strains of the genus Haloarcula is the presence of at least two heterogeneous $16 \mathrm{~S}$ rRNA genes. During our surveys on halophilic archaeal diversity of the Aibi salt lake $\left(82^{\circ} 35^{\prime}-83^{\circ} 16^{\prime}\right.$ E $\left.44^{\circ} 05^{\prime}-45^{\circ} 08^{\prime} \mathrm{N}\right)$ in the Xin-Jiang region of China (Cui et al., 2006), a strain that harboured three heterogeneous $16 \mathrm{~S}$ rRNA genes and that clustered tightly with members of the genus Haloarcula was obtained.

Strain $\mathrm{BD}-3^{\mathrm{T}}$ was isolated from sediment of Aibi salt lake ( $\mathrm{pH} 8.1,112.4 \mathrm{~g}$ salt $^{-1}$ ), the largest salt lake in the region. The standard growth medium used for strain $\mathrm{BD}-3^{\mathrm{T}}$ and other Haloarcula strains contained $\left(\mathrm{g} \mathrm{l}^{-1}\right)$ : Casamino acids (Difco), 7.5; yeast extract (Difco), 10; trisodium citrate, 3.0; $\mathrm{MgCl}_{2} \cdot 6 \mathrm{H}_{2} \mathrm{O}, 10.2 ; \mathrm{KCl}, 20 ; \mathrm{FeSO}_{4} .7 \mathrm{H}_{2} \mathrm{O}, 0.05 ; \mathrm{NaCl}, 180$

The GenBank/EMBL/DDBJ accession numbers for the three $16 \mathrm{~S}$ rRNA gene sequences of strain BD-3 ${ }^{\top}$ are DQ826512, DQ826513 and DQ854818.

A thin-layer chromatogram of total polar lipids from strain BD-3 ${ }^{\top}$ and members of the genus Haloarcula is available as supplementary material in IJSEM Online.
( $\mathrm{pH}$ adjusted to 7.2 with $1 \mathrm{M} \mathrm{NaOH}$ solution). The methods used for isolation were as described by Xin et al. (2000).

Phenotypic tests were performed according to the proposed minimal standards for the description of new taxa in the order Halobacteriales (Oren et al., 1997). Cell motility and morphology were examined by phase-contrast microscopy of exponentially growing liquid cultures. Gram staining was carried out as described by Dussault (1955). Colony morphology was observed on salt-milk and the standard growth agar medium after incubation at $40^{\circ} \mathrm{C}$ for 6-10 days. Anaerobic growth was tested in the presence of $5 \mathrm{~g}$ sodium nitrate, L-arginine or DMSO per litre in filled, stoppered tubes. To determine growth $\mathrm{pH}$ range (using increments of $0.5 \mathrm{pH}$ units, from $\mathrm{pH} 5.0$ to 10.0), $25 \mathrm{mM}$ MES (pH 5.0-6.7), $25 \mathrm{mM}$ PIPES (pH 6.1-7.5), $25 \mathrm{mM}$ MOPS (pH 6.5-7.9), 25 mM HEPES (pH 6.8-8.2), 25 mM Tricine (pH 7.4-8.8) and $25 \mathrm{mM}$ CHES ( $\mathrm{pH}$ 8.6-10.0) were used. Tests for catalase and oxidase activities and hydrolysis of starch and of Tweens 20, 40, 60 and 80 were performed as described by Gonzalez et al. (1978). Nitrate reduction, $\mathrm{H}_{2} \mathrm{~S}$ formation, indole formation, and utilization of carbohydrates, sugar alcohols, amino acids and organic acids were examined as described by Oren et al. (1997).

Polar lipids were extracted with chloroform/methanol as described by Kamekura (1993). One- and two-dimensional TLC was performed by using silica gel plates (Kieselgel $60 \mathrm{~F}$; Merck) (Kates, 1986).

DNA was extracted by using phenol/chloroform extraction followed by ethanol precipitation, as modified according to $\mathrm{Ng}$ et al. (1995). The gene encoding $16 \mathrm{~S}$ rRNA was amplified 


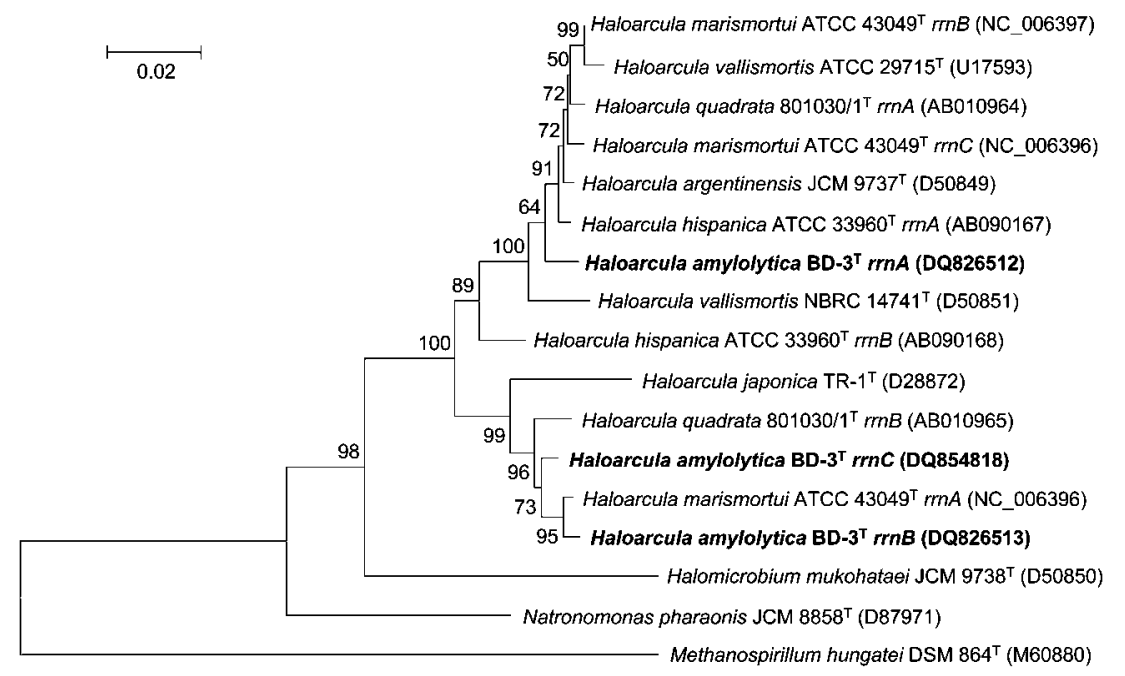

Fig. 1. Neighbour-joining phylogenetic tree based on 16S rRNA gene sequences showing the relationship between strain $B D-3^{\top}$ and other members of the genus Haloarcula. Bootstrap values (expressed as percentages of 1000 replicates) greater than $49 \%$ are shown at branch points. Bar, 0.02 expected changes per site.

by PCR with the forward primer 5'-TTCCGGTTGATCCTGCC-3' (positions 7-23, according to the Escherichia coli numbering scheme) and the reverse primer 5'-AAGGAGGTGATCCAGCC-3' (positions 1541-1525), modified according to Achenbach \& Woese (1995). PCR was performed for 30 cycles with denaturation for $1 \mathrm{~min}$ at $95^{\circ} \mathrm{C}$, annealing for $1 \mathrm{~min}$ at $49^{\circ} \mathrm{C}$ and polymerization for $90 \mathrm{~s}$ at $72^{\circ} \mathrm{C}$. The PCR product was cloned into T-vector, and sequenced by using an ABI BigDye3.1 sequencing kit (Applied Biosystems) and an automated DNA sequencer (model ABI3730; Applied Biosystems). Phylogenetic analyses were conducted using the neighbour-joining method (MEGA version 3.1; Kumar et al., 2004).

The $\mathrm{G}+\mathrm{C}$ content of the DNA was determined by using the thermal denaturation method (Marmur \& Doty, 1962), with a Beckman UV-Vis DU800 spectrophotometer at $260 \mathrm{~nm}$.
DNA-DNA hybridization was carried out by the thermal denaturation and renaturation method (De Ley et al., 1970) as modified by Huß et al. (1983).

Cells of strain BD- $3^{\mathrm{T}}$ were Gram-negative, motile rods, and were able to grow over a wide range of salinities (2.0-5.1 M $\mathrm{NaCl}$; optimal growth at 2.9-3.2 M). Cells lysed in distilled water and $5 \%$ brine. Colonies on salt-milk agar medium were red-pigmented. Phenotypic characteristics of strain $\mathrm{BD}-3^{\mathrm{T}}$ are given in the species description below and Table 1. As detailed in Table 1 , strain $\mathrm{BD}-3^{\mathrm{T}}$ could be phenotypically differentiated from recognized Haloarcula species but had very similar phenotypic properties to $H$. hispanica ATCC $33960^{\mathrm{T}}$.

The polar lipid composition of strain $\mathrm{BD}-3^{\mathrm{T}}$ was determined to be phosphatidylglycerol, phosphatidylglycerol phosphate

Table 1. Differential phenotypic characteristics between strain BD-3 ${ }^{\top}$ and other members of the genus Haloarcula

Taxa: 1, strain BD-3 ${ }^{\mathrm{T}} ; 2$, H. marismortui ATCC $43049^{\mathrm{T}} ; 3$, H. argentinensis JCM $9737^{\mathrm{T}}$; 4, H. hispanica ATCC $33960^{\mathrm{T}}$; 5, H. japonica TR-1 ${ }^{\mathrm{T}}$; 6, H. vallismortis ATCC $29715^{\mathrm{T}}$; 7, H. quadrata 801030/1 ${ }^{\mathrm{T}}$. +, Positive; -, negative; \pm , variable; ND, not determined.

\begin{tabular}{|c|c|c|c|c|c|c|c|}
\hline Characteristic & 1 & 2 & 3 & 4 & 5 & 6 & 7 \\
\hline Optimum $\mathrm{NaCl}$ for growth $(\%)$ & 3.1 & $3.4-3.9$ & $2.5-3.0$ & $3.4-4.3$ & 3.4 & 2.5 & $2.7-4.3$ \\
\hline Cell shape & Rod & Pleomorphic & Triangular & Short rod & Triangular & Rod & Square \\
\hline \multicolumn{8}{|l|}{ Hydrolysis of: } \\
\hline Starch & + & - & + & + & - & - & + \\
\hline Gelatin liquefaction & + & - & + & + & - & - & - \\
\hline Indole formation & + & - & ND & ND & + & + & - \\
\hline \multicolumn{8}{|l|}{ Utilization of: } \\
\hline Sorbitol & + & + & - & + & + & - & + \\
\hline Mannitol & + & + & - & + & + & - & + \\
\hline
\end{tabular}


methyl ester, phosphatidylglycerosulfate, triglycosyl diether and an unknown diglycosyl diether (see Supplementary Fig. S1 in IJSEM Online). The genomic DNA G + C content of strain $\mathrm{BD}-3^{\mathrm{T}}$ was $62.4 \mathrm{~mol} \%$.

Polymorphism of $16 \mathrm{~S}$ rRNA genes of strain $\mathrm{BD}-3^{\mathrm{T}}$ was observed. Three $16 \mathrm{~S}$ rRNA genes were detected, designated $r r n A$ (1472 bp), rrnB (1472 bp) and $r r n C$ (1472 bp) (Fig. 1). The $r r n A$ gene sequence of $\mathrm{BD}-3^{\mathrm{T}}$ showed high similarities to the $r r n A$ gene sequence of $H$. hispanica (98.7\%), the $16 \mathrm{~S}$ rRNA gene sequence of $H$. argentinensis $(98.6 \%)$, and the $r r n B(98.6 \%)$ and $r r n C(98.6 \%)$ gene sequences of $H$. marismortui. The $r r n B$ gene sequence of $\mathrm{BD}-$ $3^{\mathrm{T}}$ showed highest similarity $(99.5 \%)$ to the H. marismortui $r r n A$ gene sequence. The $r r n C$ gene sequence of $\mathrm{BD}-3^{\mathrm{T}}$ showed highest similarity $(98.8 \%)$ to the $H$. marismortui $r r n A$ gene sequence and $H$. quadrata $r r n B$ gene sequence. Levels of similarity between the three 16S rRNA genes of strain BD- $3^{\mathrm{T}}$ were $95.2 \%$ ( $r r n A$ and $\left.r r n B\right), 94.6 \%(r r n A$ and $r r n C)$ and $99.0 \%(r r n B$ and $r r n C)$. DNA-DNA hybridization values between strain $\mathrm{BD}-3^{\mathrm{T}}$ and $H$. japonica JCM $7785^{\mathrm{T}}$, H. vallismortis ATCC $29715^{\mathrm{T}}, H$. hispanica ATCC $33960^{\mathrm{T}}, H$. argentinensis JCM $9737^{\mathrm{T}}, H$. quadrata JCM $11048^{\mathrm{T}}$ and H. marismortui ATCC $43049^{\mathrm{T}}$ were $30,30,34$, 38,39 and $39 \%$, respectively.

Based on these results, it is concluded that strain $\mathrm{BD}-3^{\mathrm{T}}$ represents a novel species of the genus Haloarcula, for which the name Haloarcula amylolytica sp. nov. is proposed.

\section{Description of Haloarcula amylolytica sp. nov.}

Haloarcula amylolytica (a.my.lo.ly'ti.ca. Gr. n. amylos starch; Gr. adj. lytikos dissolving; N.L. f. adj. amylolytica producing lysis of starch).

Cells are rod-shaped $(0.6-0.8 \times 2.0-2.5 \mu \mathrm{m})$, motile and Gram-negative. Colonies on salt-milk and standard growth agar plates containing $18 \%(\mathrm{w} / \mathrm{v}) \mathrm{NaCl}$ are red, elevated and round. Chemo-organotrophic and aerobic. Growth occurs at $\mathrm{NaCl}$ concentrations of $2.0-5.1 \mathrm{M}, \mathrm{Mg}^{2+}$ concentrations of 0.005-0.70 M, pH 6.5-9.0 and temperature of $20-52^{\circ} \mathrm{C}$. Optimal $\mathrm{NaCl}$ concentration, $\mathrm{Mg}^{2+}$ concentration, $\mathrm{pH}$ and temperature for growth are $2.9-3.2 \mathrm{M}, 0.10-0.30 \mathrm{M}$, $\mathrm{pH} 7.0-7.5$ and $41{ }^{\circ} \mathrm{C}$, respectively. Catalase- and oxidasepositive. Anaerobic growth occurs in the presence of nitrate with formation of nitrite and gas. No anaerobic growth in the presence of arginine or DMSO. $\mathrm{H}_{2} \mathrm{~S}$ is produced from $\mathrm{Na}_{2} \mathrm{~S}_{2} \mathrm{O}_{3}$. Indole formation is positive. Tweens $20,40,60,80$ and starch are hydrolysed. Casein is not hydrolysed. Gelatin is liquefied. Glucose, sucrose, galactose, sorbitol, mannose, mannitol and maltose are utilized and acids are produced. No growth is observed on fructose, sorbose, xylose, lactose or D-ribose. Sensitive to the following antibiotics: novobiocin $(30 \mu \mathrm{g}$ per disc) and bacitracin (0.04 IU per disc). Resistant to the following antibiotics ( $\mu$ g per disc, unless otherwise indicated): ampicillin (10), rifampicin (5), erythromycin (15), tetracycline (30), ciprofloxacin (5), chloramphenicol (30), kanamycin (30), neomycin (30), vancomycin (30), norfloxacin (10), streptomycin (10) and penicillin $\mathrm{G}$ (10 IU per disc). The molar $\mathrm{G}+\mathrm{C}$ content of the DNA is $62.4 \%\left(T_{\mathrm{m}}\right)$. The major polar lipids are phosphatidylglycerol, phosphatidylglycerol phosphate methyl ester, phosphatidylglycerosulfate, triglycosyl diether and an unknown diglycosyl diether.

The type strain, BD- $3^{\mathrm{T}}\left(=\mathrm{CGMCC} 1.5335^{\mathrm{T}}=\mathrm{JCM} 13557^{\mathrm{T}}\right)$, was isolated from Aibi salt lake in Xin-Jiang, China.

\section{Acknowledgements}

This work was supported by grants from the Ministry of Science and Technology (2004CB719601) and from the Chinese Academy of Sciences (KJCX1-SW-07).

\section{References}

Achenbach, L. \& Woese, C. (1995). Appendix 11: $16 \mathrm{~S}$ and $23 \mathrm{~S}$ rRNA-like primers. In Archaea: a Laboratory Manual: Halophiles, pp. 269-271. Edited by S. DasSarma \& E. M. Fleischmann. Cold Spring Harbor, NY: Cold Spring Harbor Laboratory.

Cui, H.-L., Yang, Y., Tohty, D., Zhou, P.-J. \& Liu, S.-J. (2006). Biodiversity of halophilic archaea isolated from two salt lakes in XinJiang region of China. Acta Microbiol Sinica 46, 171-176.

De Ley, J., Cattoir, H. \& Reynaerts, A. (1970). The quantitative measurement of DNA hybridization from renaturation rates. Eur J Biochem 12, 133-142.

Dussault, H. P. (1955). An improved technique for staining red halophilic bacteria. J Bacteriol 70, 484-485.

Elazari-Volcani, B. (1957). Genus XII. Halobacterium ElazariVolcani, pp. 207-212. In Bergey's Manual of Determinative Bacteriology, 7th edn. Edited by R. S. Breed, R. G. D. Murray \& N. R. Smith. Baltimore: Williams \& Wilkins.

Gonzalez, C., Gutierrez, C. \& Ramirez, C. (1978). Halobacterium vallismortis sp. nov. An amylolytic and carbohydrate-metabolizing, extremely halophilic bacterium. Can J Microbiol 24, 710-715.

Huß, V. A. R., Festl, H. \& Schleifer, K.-H. (1983). Studies on the spectrometric determination of DNA hybridisation from renaturation rates. Syst Appl Microbiol 4, 184-192.

Ihara, K., Watanabe, S. \& Tamura, T. (1997). Haloarcula argentinensis sp. nov. and Haloarcula mukohataei sp. nov., two new extremely halophilic archaea collected in Argentina. Int J Syst Bacteriol 47, 73-77.

Javor, B., Requadt, C. \& Stoeckenius, W. (1982). Box-shaped halophilic bacteria. J Bacteriol 151, 1532-1542.

Juez, G., Rodriguez-Valera, F., Ventosa, A. \& Kushner, D. J. (1986). Haloarcula hispanica spec. nov. and Haloferax gibbonsii spec. nov., two new species of extremely halophilic archaebacteria. Syst Appl Microbiol 8, 75-79.

Kamekura, M. (1993). Lipids of extreme halophiles. In The Biology of Halophilic Bacteria, pp. 135-161. Edited by R. H. Vreeland \& L. I. Hochstein. Boca Raton, FL: CRC Press.

Kates, M. (1986). Techniques of Lipidology, 2nd edn. Amsterdam: Elsevier.

Kumar, S., Tamura, K. \& Nei, M. (2004). MEGA3: integrated software for molecular evolutionary genetics analysis and sequence alignment. Brief Bioinform 5, 150-163. 
Marmur, J. \& Doty, P. (1962). Determination of the base composition of deoxyribonucleic acid from its thermal denaturation temperature. J Mol Biol 5, 109-118.

Ng, W. L., Yang, C. F., Halladay, J. T., Arora, A. \& DasSarma, S. (1995). Protocol 25: isolation of genomic and plasmid DNAs from Halobacterium halobium. In Archaea: a Laboratory Manual: Halophiles, pp. 179-180. Edited by S. DasSarma \& E. M. Fleischmann. Cold Spring Harbor, NY: Cold Spring Harbor Laboratory.

Oren, A., Ginzburg, M., Ginzburg, B. Z., Hochstein, L. I. \& Volcani, B. E. (1990). Haloarcula marismortui (Volcani) sp. nov., nom. rev., an extremely halophilic bacterium from the Dead Sea. Int J Syst Bacteriol 40, 209-210.

Oren, A., Ventosa, A. \& Grant, W. D. (1997). Proposed minimal standards for description of new taxa in the order Halobacteriales. Int J Syst Bacteriol 47, 233-238.
Oren, A., Ventosa, A., Gutiérrez, M. C. \& Kamekura, M. (1999). Haloarcula quadrata sp. nov., a square, motile archaeon isolated from a brine pool in Sinai (Egypt). Int J Syst Bacteriol 49, 1149-1155.

Takashina, T., Hamamoto, T., Otozai, K., Grant, W. D. \& Horikoshi, K. (1990). Haloarcula japonica sp. nov., a new triangular halophilic archaebacterium. Syst Appl Microbiol 13, 177-181.

Torreblanca, M., Rodriguez-Valera, F., Juez, G., Ventosa, A., Kamekura, M. \& Kates, M. (1986). Classification of non-alkaliphilic halobacteria based on numerical taxonomy and polar lipid composition, and description of Haloarcula gen. nov. and Haloferax gen. nov. Syst Appl Microbiol 8, 89-99.

Xin, H., Itoh, T., Zhou, P., Suzuki, K., Kamekura, M. \& Nakase, T. (2000). Natrinema versiforme sp. nov., an extremely halophilic archaeon from Aibi salt lake, Xinjiang, China. Int J Syst Evol Microbiol 50, 1297-1303. 